\title{
BLODETS RÖST
}

\section{Pseudonymen Elsa Gille}

Det finns en roman från den svenska 1900-talslitteraturens två första decennier där den erotiska passionen mellan två kvinnor är huvudmotiv och där det inte ges någon möjlighet att blunda för relationens sexuella karaktär. En enda. Den heter Vi stackars kvinnor... och gavs ut på Albert Bonniers förlag 1917. Vem som skrev den är oklart, men som författare står pseudonymen Elsa Gille. ${ }^{1}$ Troligen är det anonymiteten som gör att romanen är så frispråkig som den faktiskt är.

Det var Kristin Järvstad som nyupptäckte romanen när hon gick igenom alla samtidsromaner skrivna av kvinnliga författare 18901920 för sin bok Den kluvna kvinnligheten (2008). Genom denna metod fick Järvstad syn på en roman som förbigicks med tystnad när den utkom, troligen för att den var alltför explicit i skildringen av det förbjudna, och som sedan ingen verkar ha brytt sig om. Det mesta som publiceras faller snabbt i glömska, ibland för att det inte passar tidens värderingar, litterära och andra, ibland för att det passar alltför bra. Man kan bara spekulera över hur många berättelser om den förbjudna kärleken det kan tänkas finnas i den svenska litteraturens historia om man systematiskt skulle leta efter dem.

Men Vi stackars kvinnor ... var inte helt glömd. Den dök nämligen upp i en fotnot i den antifeministiska pamfletten Kätterier $i$ kvinnofrågan (1924) av Arnold Sölvén, en man som senare skulle komma att bli en ledande jurist inom LO. Pamfletten är en vidräkning med kvinnorörelsen, som Sölvén ansåg redan hade gått alldeles långt. Rösträtten, den nya äktenskapslagen och behörighetslagen fick vara nog, tyckte han; att därefter fortsätta den feministiska kampen var "fanatism" som skulle leda till "könsdifferentieringens utplånan- 
de". Som så ofta i den antifeministiska retoriken försökte Sölvén avväpna kvinnorörelsekvinnorna genom beskyllningen om tribadism:

Det är i själva verket ingen art- endast en gradskillnad mellan tribaden å ena sidan och å den andra den intellektuella amazonen och den blaserade, illusionsfria kvinnliga bohêmen, sådana de i våra moderna kvinnoromaner figurera som representanter för det nya kvinnoidealet. ${ }^{2}$

Så långt uttryckte han ungefär samma värderingar som August Strindberg, Ellen Key, Otto Weininger och andra brukade göra, men det intressanta är att Sölvén också presenterar en hel liten bibliografi över svenska romaner om samkönad kärlek. Så vitt känt är detta den första i sitt slag.

Det är karaktäristiskt i vilken omfattning i motivkretsen för denna litteratur upptagits homosexualiteten. Av endast från de fem senaste åren härrörande litteratur med detta motiv må nämnas Elsa Gille, Vi stackars kvinnor...; Agnes von Krusenstjerna, Tony växer upp; Alma Söderhjelm, Kärlekens väninna och Den flygande holländaren; Karin Smirnoff, Ödesmärkt samt - ställvis - Anna Lenah Elgström, En romantikers hustru. Något bidrag av manliga författare till denna litteratur under samma tid är mig inte bekant. ${ }^{3}$

Sölvén kunde ju ha nämnt Frida Stéenhoff, men han verkar inte känna till henne. Han kunde ha nämnt Anna Branting, som snuddade vid motivet begär mellan kvinnor i debutromanen Lena. En bok om fruntimmer (1893) och Helena Nyblom, som i ungdomsromanen Sju flickor (1915) berättar om den unga Maria som klär sig manligt och älskar sin väninna över allt annat trots att kärleken inte är besvarad. ${ }^{4}$

Han kunde också ha lyft fram Ola Hanssons redan nämnda Tidens kvinnor (1914), där dekadensens hermafroditiska och sapfiska kvinnomonster passerar revy. I novellen "I dampensionen" låter det till exempel så här:

och så har man dubbelmänniskan med kvinnliga organ och man- 
lig själ, hos vilken ävenledes könet är ett, det intellektuella och affektiva väsendet ett annat, $-\mathrm{m}$. a. o. brunsten isolerad, utplånad eller förråad. - Och dock: djupare nere ligga ödesdigrare, gåtfullare makter, den nedärvda dispositionen, atavism eller degeneration, återfall eller överkultur, och den födda dubbelmänniskan står inför oss, ett monster från moderlivet, ett tvedelt väsen ända ifrån embryonet, en jag-komplex i en och samma kropp, inom vilken de två varelserna, man och kvinna, Adam och Eva, le mâle och la femelle, slingra sig om varandra som långa vita ormar, i fantasiens sterila brånad och i en evigt otillfredsställd och otillfredsställbar vällusts spasmer. ${ }^{4 \mathrm{~b}}$

I stället är det alltså Elsa Gille som blir först ut. För Sölvén var detta sannerligen inte tänkt som någon ärebetygelse.

\section{Mot sagans land}

Den kärlekspassion som utgör navet i Vi stackars kvinnor... förklaras aldrig bort som vänskap, systerskap eller något annat oförargligt. Det handlar om blodets röst, alltså om erotiska begär, även om känslorna aldrig ges några namn i berättelsen. Viveka Heineman, den ena av de älskande kvinnorna, kallas av skvallret för "en sådan där, som har till specialitet att dra till sig unga flickor". 5 Sälv talar hon om "två människor, så beskaffade som du och jag". (111)

Insprängda mellan eruptioner av skuld- och skamkänslor finns det i romanen flera apologier för den samkönade kärleken. Viveka Heineman, den mer erfarna av de två älskande, säger till exempel vid ett tillfälle:

Ja, jag förstår inte, hur jag någonsin kunnat tycka att det är synd eller orätt eller föraktligt ... Är inte kulturens försyndelser mot vår natur vida större och orättfärdigare, då den fordrar att vi ett helt långt liv skall förneka vårt blod och leva som könlösa varelser? (92)

Flera gånger i texten sägs det att den samkönade kärleken kan vara ett slags ersättning för den "verkliga" kärleken, alltså den olikkönade, 
och tanken framsägs i ordalag som liknar dem hos Elisabeth Dauthendey och Frida Stéenhoff. Men den har egentligen ingen förankring i den berättelse läsaren faktiskt möter, för den olikkönade kärleken uppmärksammas knappt alls i romanen medan den samkönade skildras som något långt mer dramatiskt än bara svärmisk vänskap. Det handlar om begär som de älskande själva inte råder över, om förtärande passioner som leder till utstötning ur den samhälleliga gemenskapen.

Orden "kulturens försyndelser mot vår natur" i citatet ovan är nog en anspelning på (den homosexuelle) filosofen Pontus Wikners uppmärksammade essä "Kulturens offerväsen", där han utan att ge några lösningar lyfte fram konflikten mellan å ena sidan människornas ostyriga känslor och å andra sidan äktenskapets samhälleliga betydelse. Begär som inte rymdes inom denna institution måste helt enkelt bekämpas. Som vi ska se längre fram var Wikners essä en återkommande referens hos författare som skrev om ickeheteronormativa erfarenheter under decennierna runt 1900.

Vi stackars kvinnor ... innehåller ideliga perspektivbyten. Heterosamhällets perspektiv får brytas mot de älskandes perspektiv, och inom den unga Thyra Börjesson själv sker det våldsamma svängningar mellan å ena sidan frestelsen att bejaka passionen och å andra sidan viljan att leva i enlighet med samhällets normer. Thyra, som är berättelsens centrala medvetande, funderar över den förhärskande sexualmoralen:

Och samvetskvalen? - Voro de väl annat än en produkt av de rådande sedlighetsbegreppen - sedlighetsbegreppen, som människorna själva skapade åt sig och som växlade genom tiderna? Ty det var sant: moralen var icke helt densamma idag som i går. I de starkas händer formades den ideligen om på nytt ... (108)

Den som öppnar berättelsen är Thyras kamrat, Lisa Ljungh, en kvinna som står med båda fötterna tryggt förankrade i heteronormativiteten. ${ }^{6}$ När Lisa råkar få syn på Thyras dödsannons får hon impulsen att berätta väninnans historia, trots att de då sedan länge har förlorat kontakten med varandra och trots att Lisa aldrig förstod vad som 
hände i Thyras känslovärld. "Ett kors över ett namn som en gång var mig kärt!” Så lyder romanens allra första mening, men när berättelsen sedan rullar igång marginaliseras Lisa, både som berättarröst och väninnegestalt i romanen. I stället blir hon en bärare av det onda skvaller som plågar de älskande.

Efter den korta ramberättelsen förs läsaren raskt in mot berättelsens känslocentrum och vägen dit löper parallellt med en resa i den geografiska verkligheten, bort från vardagsplikternas Stockholm och fram mot nya känslovärldar i ett idylliskt ferielandskap, närmare bestämt mot fröken Pampes pensionat. Det är en lång och ansträngande resa, först med tåg och sedan med häst och vagn, och under denna resa förs Thyra och Lisa bort från ett medvetandetillstånd och fram mot ett annat, bort från verkligheten och in i sagan.

Under resans gång får vi en inblick i vad som rör sig inom Thyra. Hon ser på det landskap de reser igenom och klagar - ganska omotiverat som det senare visar sig - över att hon inte kan måla. Hennes förtvivlan gäller hennes konstnärsliv, men de ord hon använder förebådar det som snart kommer att bli hennes kärleksliv:

- Vet du, ibland när det riktigt går upp för mig, att jag hör till dessa olyckliga som fått konstnärslängtan i blodet utan förmågan att kunna nå fram - ja, då förbannar jag ödet, som låtit mig födas. Ni som sluppit från denna olycksaliga halvhet, ni förstår inte vad det vill säga att vara ... att vara som jag ... aldrig ro, aldrig tillfredsställelse, bara längtan, längtan, längtan utan återvändo. (13-14)

Lisa Ljungh försöker muntra upp henne med att hennes konstnärskap trots allt har varit ganska framgångsrikt, men Thyra låter sig inte tröstas: "Du tror det kanske inte, men likafullt är det så: det finns stunder då jag avskyr mig själv, därför att jag inte har kraft eller mod att bryta med det gamla och gå nya vägar..." (15) Återigen gäller det hennes yrke, men orden kunde lika gärna ha gällt den kärlekspassion som hon utan att ännu veta om det är på väg att möta. De båda resenärerna blir allt tröttare; Thyra faller in i ett slags halvslummer och vardagsverkligheten övergår i en underlig drömvärld. Thyra tycker att vagnen de reser i blir större och större 
och att den lyfter från marken "hän mot ett stort svart moln, som hotfullt tornade vid horisonten", ett moln som sedan omvandlas till att bli något annat, "något oförklarligt och hemskt, hon visste icke vad". (16) Och sedan är Thyra framme vid det ångestcentrum som hon sedan ofta, ofta återvänder till under berättelsens gång.

En outsäglig ångest började slita inom henne. Med ett svagt rop kröp hon ihop med armarna skyddande över huvudet och sökte gömma sig undan. Men i samma ögonblick sköt en jättestor arm likt en ljungande blixt fram ur det hemlighetsfulla mörkret och träffade med knuten hand i ett vinande, obarmhärtigt slag hennes ångestfullt krökta rygg... (16-17)

Väl framme vid fröken Pampes pensionat möts de av en till synes trygg och ljus sagovärld, men det är en värld som också rymmer underliga varelser och oanade faror. För Thyra vill säga, Lisa lämnar aldrig det soligt vardagliga.

När Thyra nästa dag vaknar, utsövd efter den tröttande resan, tittar hon ut genom fönstret och njuter av trädgården och den härliga sommarmorgonen. Hon visslar en glad melodi och den ena foten rör sig i takt med musiken då hon plötsligt får syn på något som fångar hela hennes uppmärksamhet:

Alldeles under hennes fönster, på en av starrgräs nästan övervuxen träbänk, solade sig en underlig liten man. Huvudet satt inkilat mellan de smala, höga axlarna, rygg och bröst sköto ut i pucklig båge, och de spetsiga rockskörten hängde rätt ned och över varandra som ett hopfällt vingpar. Det såg ut som en jättefågel slagit ner på bänken och försjunkit i tankar. (21)

Thyra tittar ogenerat ner på honom från sitt fönster, nyfiket och undersökande, "som om hon betraktat ett sällsynt djur, icke en mänsklig varelse". Den främmande mannen förstår snart att han är iakttagen, blir förlägen och skyggar med blicken, men när han sedan ser hennes kritiska granskning av hela hans person börjar han titta tillbaka: 
En lång stund sågo de båda oavvänt på varandra. Så började det plötsligt rycka kring mungiporna på hans breda svalmun, läpparna skildes långsamt, så att de starka, vita tänderna lyste fram. Med en tveksam, bortkommen rörelse höjde han plötsligt sin långa spindelarm och lyfte förläget hälsande på mössan. (21-22)

Hon trodde sig vara suverän i sin blick på honom och världen, men när han tittar tillbaka trotsar han hennes förakt, återtar sin mänskliga värdighet och får henne att plötsligt skämmas över sitt övermod. Men samtidigt gör det henne rasande att han har tagit sig denna frihet, "detta var helt enkelt oerhört, fräckt, en personlig förolämpning!"

Fågelmannen växer under berättelsens gång till att bli en parallellgestalt till Thyra själv och hon kan inte längre förstå att hon en gång "kunnat ligga i fönstret och titta på den stackars Gerle så, som hon gjorde den där morgonen ...” (40). Den indignation och ångest hon känner när han samlar mod och möter hennes kritiska blick, är densamma som hon längre fram kommer att känna när hon möter sig själv efter det att hon har gett efter för sina erotiska begär. Och den är densamma som romanens heteropersoner visar inför dess homopersoner. När den Andra, den marginaliserade, trotsar föraktet, om än tveksamt och trevande, blir det tydligt att marginaliseringen handlar om sociala maktförhållanden och inte om naturgivna omständigheter. Fågelmannen är lika mycket människa som Thyra och har samma rätt till respekt som hon.

Thyra och fågelmannen kommer att träffas ännu en gång under berättelsens gång. Då har det gått ett helt år och båda har återvänt till fröken Pampes pensionat. Då är Thyra förälskad i Viveka och han är förälskad i henne själv och båda är förvisade från den värld där de lyckliga människorna bor. Hon därför att hon älskar en kvinna och dessutom en kvinna som hon tror att hon inte kan få. Han därför att hans kropp är deformerad och för att han älskar en kvinna som han vet att han inte kan få. De tillbringar en midsommarkväll tillsammans och ser på de vanliga människornas dans och kärleksglädje för att sedan skiljas åt och var för sig hänge sig åt sorgliga tankar. Hon diktar: "Ack, sant är blott ett: jag är ofri och usel en slav, när 
pulsarna hamra och blodet bedårande sjunger." Han funderar över "varför hans usla, vanskapta kropp fått ett så stort och varmt och rött hjärta. Ack, livet var icke stort annat än bitterhet och ironi." (141)

Hans kärlekslängtan är lika het och hopplös som hennes och hans yttre deformation korresponderar med den inre deformation som brukade tillskrivas den som älskade någon av samma kön. Vi har ju redan sett ett exempel på det i Frida Stéenhoffs novell "Ett sällsamt öde". Skildringen av den puckelryggige mannen och den lesbiska kvinnan, som båda tillhör samhällets utstötta, pendlar mellan å ena sidan sympati och respekt och å andra sidan ringaktning och medlidande.

\section{Från marginalen}

Berättelsens kärlekspar, Thyra och Viveka, möts genom att de delar ett utifrånperspektiv på gästerna på fröken Pampes pensionat. Thyra känner ett starkt förakt när hon ser hur de andra pensionatsgästerna trängs runt matbordet, ivriga att ta för sig av anrättningarna. I en aggressiv fantasi liknar hon dem vid skadedjur: "Sådana gräshoppor borde man sannerligen också ha rätt att sopa ner i grävda diken och hälla över med fotogen ..." (25) Vad ordet "också" syftar på framgår inte, Egyptens gräshoppor kanske. Viveka ser på henne och uppfattar hennes tankar.

- Jag kan se, att skådespelet gör samma effekt på er som på mig själv, sade plötsligt en mjuk röst alldeles invid hennes öra. Thyra såg upp överraskad. Framför henne stod en medelålders, elegant dam och log emot henne med gropar i kinderna. Hennes stora, bruna ögon hade en milt sugande blick.

En blixtsnabb känsla av beklämmande motvilja, blandad med nyfiket intresse, for genom Thyra Börjesson. Hon undrade över, att hon icke genast vid sitt inträde i matsalen givit akt på denna ståtliga, soignerade företeelse. (25)

Här är det Viveka och Thyra som ser på andra människor med förakt, men andra gånger är det de själva som blir utsatta för kritisk 
granskning. Berättelsen spelar hela tiden med olika perspektiv på de centrala karaktärerna och händelserna. Förakt för normaliteten och normativiteten varvas med förakt för den och det som inte ryms där. När Thyra nu ser på Viveka är det med lika delar attraktion och motvilja. "Hon kände sig underligt bortkommen och generad inför fru von Heineman." (26) Scenen avslutas med att vännen Lisa, som kämpat bland "gräshopporna" runt maten, kommer till deras bord. Hon, som är normalitetens upprätthållare i berättelsen, uppträder fientligt mot Viveka.

Dagarna går och Viveka närmar sig Thyra alltmer. De träffas i naturen, långt från pensionatets kontrollerade värld. Hon följer efter Thyra när hon är ute i naturen och målar, smeker hennes hår och beundrar hennes vackra händer. Lisa blir alltmer kritisk till att Thyra umgås med Viveka: "Jag tycker inte om att den där Heinemanskan springer efter dig jämt. Du borde akta dig, Thyra!" (29) Thyra replikerar med att Lisa själv umgås med en skara beundrande män, men det är något helt annat tycker Lisa, för det är ju bara som det ska vara: "När ett fruntimmer smickrar ett annat fruntimmer, är där alltid något sattyg under." (30) Hon går på så mycket att Thyra börjar fundera på om väninnan kan vara svartsjuk.

- Ja, du är god du! Jag börjar nästan tro, att du är "svart" på stackars Heineman.

- "Svart!" fnös Lisa föraktligt. Det ordet finns inte i mitt privatlexikon skall jag säga dig. Men jag vädrar olycka, som jätten kristet blod, fastän jag omöjligt med mitt förstånd kan utfundera, att någon fara är å färde. (31)

Lisa kan själv inte förstå varför hon är så orolig för sin väninna, men sedan gör hon en liknelse som - paradoxalt nog - slår an ett motiv som på ett underliggande plan genljuder genom hela romanen. Viveka Heineman görs till en kristen martyr. Lisa säger ju att hon "vädrar olycka, som jätten kristet blod". Hon tar till liknelsen för att marginalisera Viveka, men på ett underliggande plan fungerar den på ett motsatt sätt. Lisa förknippar ju sig själv med jättar, som i folktron brukar ges negativa konnotationer, medan Viveka associe- 
ras med kristet blod, med martyrskap. Som enstaka företeelse skulle denna detalj knappast vara betydelsebärande, men martyrmotivet återkommer gång på gång.

En kväll när Thyra har huvudvärk kommer Viveka till hennes rum för att ge henne massage. Thyra njuter av behandlingen och känner sig "underlig" till mods, ett ord som ofta brukade användes för att beteckna erotiskt begär i tidens litteratur. Thyra vill "sätta sig till motstånd", men kan inte. Scenen slutar med att hon passionerat kysser Vivekas händer.

På natten efteråt kan hon inte sova. Thyra tycker sig se Viveka överallt. Hon skymtar fram mellan "de söndertrasade, drivande skyarna" som "en blekgul, sjuk måne", som vemodigt ser ner på henne. (38) Hon tycker sig till och med se den andra sitta på en stol bredvid sin säng. Hon känner sig hypnotiserad av något hon inte förstår vad det är. Känsloläget liknar det som målas upp av Joseph Sheridan Le Fanu i vampyrklassikern Carmilla från 1871, där erotisk passion mellan kvinnor är förknippad med vampyrism. Blodet som metafor för erotisk passion i Gilles roman pekar åt samma håll.

Här, som så ofta i romanen, finns det en djup ambivalens i bilden av Viveka. Thyra vill värja sig för henne, men kan inte. Eller är det kanske den andra kvinnan som försöker säga nej? Eller handlar det om kärlekslängtan i ett sexualfientligt och heteronormativt samhälle? Följande rader kan nog läsas på flera olika sätt.

Tänk, hon kunde höra klockan gå därinne i rummet bredvid! Den tickade så högtidligt och långsamt, helt annorlunda än hennes... $\mathrm{Nu}$ var det precis som om de talade med varandra, den stora därinne och den lilla på bordet bredvid hennes säng. Den lilla tiggde så ivrigt om något, men den stora var alltjämt lika avvisande och upprepade oryggligt sitt: nej - nej - nej - nej. (41)

Solen går upp, månen försvinner och Thyra kan äntligen somna, men hon vaknar snart av att pensionatets hund skäller på en katt som den har jagat upp i ett träd. Katten kryper ihop uppe i trädet "och följde med ondskefullt gnistrande ögon och skrämda huvudrörelser förföljaren”. (45) Hunden kommer att dyka upp flera gånger 
i berättelsen, dels i rollen som Thyras trogna följeslagare, dels, som här, i rollen som ordningsvakt. Katten, som förskrämd flytt upp i trädet, blir en sinnebild för det förbjudna begär som finns inom henne själv och som hon försöker jaga bort. Den sitter hopkrupen, precis som hon själv gjorde några dagar tidigare när hon på resan till pensionatet plötsligt greps av ångest.?

Vid frukosten försöker Thyra att undvika Viveka och drar sig inte ens för att uppföra sig direkt oartigt. Hon slår sig inte ner vid den andras bord trots att hon sitter ensam och trots att de ju delade massagens intimitet kvällen innan. Men Viveka söker upp henne och frågar Thyra om hon har tänkt på henne. Lite oväntat antyds martyrmotivet ännu en gång i Thyras svar och även nu är det Viveka som associeras med martyrskap:

- Åjo, svarade hon torrt. Jag kan nästan säga som Pilati hustru: jag har lidit mycket i drömmen i natt.

Fru von Heineman sade ingenting. Hon slöt ögonen och log strålande lyckligt. (49)

I denna liknelse görs Viveka återigen till en kristen martyr, närmare bestämt till Jesus själv. Bibeln berättar ju om att Pilatus hustru natten före rättegången mot Jesus drömde om honom och bad sin make att skona honom med orden: "Befatta dig icke med denne rättfärdige man; ty jag har i natt lidit mycket i drömmen för hans skull." ${ }^{8}$ Kanske ska man tolka det så att Thyra inte riktigt förstår vad hon säger, men klart är att Viveka gör det. Thyra försöker hålla sig undan, men slumpen för dem samman än en gång.

- Ni dumma barn, sade [fru von Heineman] slutligen, varför flyr ni den, som ni håller så mycket av?

Thyra Börjessons ansikte fick ett uttryck av så oförställd häpnad, att fru von Heineman brast ut i ett klingande, glatt skratt.

- Ja, se ni gärna så där stort och förvånat och förolämpat på mig, det hjälper ej. Förstår ni er inte själv så gör jag det. (51)

Viveka frågar varför Thyra håller sig undan från henne. "Vad vill 
ni mig?" undrar Thyra misstroget och får svaret: "En ung och en gammal kvinna kan ha mycket att ge varandra." Tidigare har Viveka kallat Thyra för "barn" men nu kallar hon henne en ung kvinna och inbjuder till någon form av närmande.

- Jag vet inte varför, men jag känner mig rädd för er. Det gjorde jag från första stunden ... Ibland tror jag, att Lisa har rätt, att ni inte är en bra människa och att försynen kanske vill varna mig ... Jag har aldrig förr känt mig skrämd för någon människa ... åtminstone inte på detta sätt... (54)

Den här gången tycker Viveka att Thyra går för långt och de skiljs åt i osämja. Thyra känner sig villrådig och olycklig över att ha gjort som hon har gjort. Det handlar om någon form av självbevarelsedrift, tror hon, men när hon inför sig själv försöker ge ord åt sina motstridiga känslor blir hon bara än mer förvirrad.

Till sin skam måste hon erkänna, att hon inga andra skäl haft än att fru von Heineman hade underliga, bottenlöst djupa ögon och ett sällsamt, mjukt leende, och att hon själv varit febersjuk en natt och legat och fantiserat om henne ... (55-56)

Thyra är kort sagt hjälplöst attraherad av den andra, även om hon inte erkänner det ens inför sig själv. Hon berättar valda delar av vad som skett för Lisa och de beslutar sig för att omedelbart lämna pensionatet. Och därmed är det slut på den första akten.

\section{Som en sömngångare}

I nästa scen har det blivit höst och Thyra arbetar i sin ateljé. Hon är tillfreds med sin tillvaro och koncentrerad på sitt måleri. Då kommer Viveka på oväntat besök. De går på operan tillsammans, där en okänd dam studerar dem i en teaterkikare så ihärdigt att Viveka blir besvärad. Därefter åker de hem till Vivekas eleganta våning för att äta supé. Jungfrun tittar så menande på Thyra att hon känner sig besvärad. Viveka föreslår att de ska lägga bort titlarna med varandra 
- men bara när de är ensamma, ett förslag som Thyra tar som en förolämpning.

- Jag börjar tro, att vi känner och tänker mycket olika, sade Thyra tvärt.

Ett blixtsnabbt leende lyste upp fru von Heinemans drag.

- Det gör vi inte, sade hon bestämt och lågt med en underlig anstrykning av glädje i rösten. (71-72)

Och därefter sker förförelsen. Det är Viveka som lockar och leder skeendet, men det är Thyra som står för den avgörande gesten.

Som i en dröm lyfte Thyra sin blick och såg motståndslöst, oavlåtligt in $\mathrm{i}$ tvenne ögon alldeles intill hennes egna, djupa, sugande som en brunn och med en rödskimrande glans längst inne bakom pupillerna. Det rev och slet inom henne av en underlig, ångestblandad lustkänsla. Det blev rött för hennes ögon. Det var som sveptes hon in i ett hölje av skimrande, glödande, brinnande eterångor, som brände hennes hud och omtöcknade hennes sinnen.

Plötsligt lyfte hon, automatiskt som en sömngångare, sina armar, slingrade dem om fru von Heinemans hals och tryckte sig häftigt intill henne. (72)

Thyra tillbringar natten hos Viveka, men när hon vaknar efter några timmars sömn är det inte längre kärlekslycka hon känner utan en rasande ångest. Hon känner sig drabbad av "förnedring", "skam" och "synd", ord som speglar den med romanen samtida homofobin, men som inte passar ihop med den person Thyra tidigare har varit i berättelsen. När hon smyger sig hem blir hon sexuellt trakasserad av en man på gatan, något hon i sitt självförakt tycker sig ha gjort sig förtjänt av. Att ha sex med en kvinna görs i denna scen till något lika föraktligt som att sälja sex till okända män. I ateljén håller hon en lång inre monolog, som börjar med de händelser hon nyss har varit med om, men som sedan viker av mot helt andra erfarenhetsvärldar än hennes egna för att slutligen komma tillbaka till henne själv igen. Den börjar: 
Och hon som trott, att hon nu var en stark, fri människa, som äntligen hade sig själv i hand, efter alla de många gångna årens strider mot kött och blod! Hon som trott, att hon aldrig skulle kunna lockas från det rättas väg av sitt blods sirénsånger!

Och nu voro alla års heta strider förgäves! (75)

Med tanke på att hon just har tillbringat sin första kärleksnatt i armarna på en kvinna, sin allra första kärleksnatt någonsin, kunde man kanske tro att monologen specifikt skulle handla om lesbisk kärlek. Men det gör den inte, i varje fall inte på något direkt sätt. Den första meningen i nedanstående citat kan visserligen läsas som en kritik mot den heteronormativa synen på kärleken:

Gud skapade en på ett sätt och själv skulle man skapa om sig på ett annat. Hela livet skulle man brottas och strida och vakta sig mot sig själv. Somliga - inte alla. Inte de gifta kvinnorna och männen. Dem tillät man allt. Dem aktade man, dem förlät man allt - även sådant, som inte borde förlåtas. Men hon och hennes ogifta systrar skulle taga sitt kors uppå sig och släpa det leende, ja, leende genom livet. (76)

Men sedan glider monologen alltmer in på förhållanden som främst handlar om heterosexualitet. Thyra anklagar den moral som säger att ogifta kvinnor inte får ha någon sexualitet alls, vare sig med män eller med kvinnor, att de till varje pris ska förtränga sina känslor och förneka sin drift. De "skulle taga sitt kors uppå sig", som orden faller. Återigen dyker martyrmotivet upp. Ogifta kvinnor som ger efter för sin kärlekslängtan föraktas, antingen som ogifta mödrar, som prostituerade eller som både ock, men de som lyckas hålla sina begär i styr har heller ingen ljus framtid att vänta.

När spåren efter de tysta lidandena och den bittra kampen började träda fram i deras ansikten [...] då skrattade fruar och män med hånande ömkan och tvetydiga blinkningar och kallade dem förkrympta, vissnade, ofärdiga varelser. (76) 
Tongångarna känns igen. Föraktet för ogifta kvinnor var utbrett i tidens litteratur och könspolitiska debatt och förekom även hos författare som August Strindberg, Ellen Key och Agnes von Krusenstjerna. Heterosexualiteten var ett obligatorium som man inte kunde smita ifrån utan att bli föremål för en eller annan form av näpst, men man fick absolut inte ägna sig åt den hur som helst. "Ty det var vordet skam att vara kvinna så, som Gud hade skapat en..." (77) Sexualiteten måste rymmas inom äktenskapet. För kvinnor, vill säga; för män gällde ju andra lagar. Den reglementerade prostitutionen var ordnad så att männen bekvämt skulle ha tillgång till kvinnokroppar, utan att denna handel skulle störa deras övriga liv. ${ }^{9}$ Riskerna och skammen skulle de prostituerade bära ensamma. Den utomäktenskapliga heterosexualiteten, även den som byggde på ömsesidiga känslor, följde i stort sett samma logik. Prästerna, moralens väktare, dundrade endast mot kvinnorna,

aldrig mot sitt eget kön, fast de inte sade det högt. Men alla männen visste det. För dem fanns det alltid tysta förbehåll. Och prästerna hjälpte dem. Det fanns två slags moral, en för män och en för kvinnor. Men vilken präst dundrade mot detta? Hade någonsin en präst dundrat mot dem, för vilkas skull prostitutionen egentligen fanns till? (78)

Det är männen som är dubbelmoralens vinnare, men inte heller de gifta kvinnorna går fria från Thyras raseri. De visar samma förakt för de ogifta kvinnorna som männen gör och spelar med i den rådande dubbelmoralen genom att förneka sina egna begär - "allesammans sade de sig inga känslor ha utan hade offrat sig för sina män och sitt fosterland”. (77) Det som är det mest förbjudna i denna monolog är kvinnors erotiska begär över huvud taget, den lesbiska kärleken är bara "det omöjligaste, det föraktligaste av allt". (80) Om kvinnors begär ska man helt enkelt tiga. "Ty det fanns saker, som aldrig fingo sägas högt, fast de voro riktiga och sanna och så många tusenden suckade under förbannelsen." (78) Eller är det kanske det samkönade begäret som åsyftas? Om det var något som det var förbjudet att tala om, så var det ju det. 
Här, som ofta, finns det ambivalenser i texten. Som läsare blir man överraskad när Thyra i sin monolog plötsligt kommer in på heterosexuella angelägenheter. Hittills har hon inte visat det minsta lilla intresse för några manspersoner. Och inte berättelsen heller. ${ }^{10}$ De män som förekommer är karikatyrer snarare än karaktärer Gerle möjligtvis undantagen, men han har å andra sidan kroppen emot sig. Att män skulle ha utgjort någon frestelse för Thyra har det aldrig varit tal om. En förklaring till att författaren låter Thyra komma in på heterosexualitet i sin sexualpolitiska utläggning trots att det är homosexualitet det handlar om i hennes liv, kunde vara författarens - och kanske förlagets - tvekan inför att väcka läsarens indignation inför förtryck av samkönad kärlek. Detta var ju en tid när såväl staten som kyrkan och vetenskapssamhället hade som uppgift att bekämpa homosexualiteten. Romanen var kanske tillräckligt uppseendeväckande som den nu blev. Bara det faktum att ingen av de älskande kvinnorna är något monster gör den ovanlig för sin tid. Priset för att skriva om samkönad kärlek var annars, som redan nämnts, att skriva fram normbrytaren som något slags icke-människa.

Thyra är upprörd över att alla tiger om de förbjudna begären, även de som själva har erfarenhet av dem: "Men hon visste, att om hon sade allt detta högt och öppet, så skulle de alla fara över henne som ett koppel tjutande hundar - även de, som visste och kände, att hon hade rätt." (77) Drevet skulle ha gått mot Thyra om hon högt hade yppat sin kritik mot den maktordning som förnekar kvinnor en egen sexualitet samtidigt som den exploaterar kvinnornas kroppar och gör samkönad kärlek till ett brott. "Nu var hon en simpel brottsling, som kunde straffas som vilken annan som helst, som stulit och rövat och mördat..." (8o) I denna text, där bildspråket ofta är starkt expressivt, kunde man kanske tro att orden bara illustrerar hur Thyra känner sig efter natten med Viveka. Men de kan också läsas bokstavligt; enligt den strafflag som gällde vid den tid då romanen utspelar sig riskerade man ju fängelsestraff upp till två år för sexuella handlingar med någon av samma kön. I lagens namn var Thyra nu en brottsling.

Det finns ännu några rader i denna inre monolog som kan vara 
värda att kommentera, nämligen de slutsatser Thyra drar strax innan hon somnar. Hon grips av något slags förtvivlans upprorsmod:

Hej, låtom oss äta och dricka, ty i morgon måste vi dö! Släpp Barabam lös, du människobarn! Vad båtar det att hela livet igenom sitta på huk och vakta med piskan en liten dygd, som inte är en dygd? (79)

Här framförs tanken att homosexualitet är förbunden med lyx och njutningslusta utan hänsyn till morgondagen, en tanke som var vanlig i samtida homofobiska fantasier samtidigt som den odlades i den strömning inom konst och litteratur som kallas dekadens och som bland annat brukar förknippas med olika former av överskridanden på könets och sexualitetens områden. I opposition mot borgerlighetens nyttomoral och naturvetenskapernas tolkningsföreträde odlade man en form av estetisk hypersensibilitet och dandyism som kom att bli stilbildande för många homosexuella män. Också kvinnoidealet byggde på olika former av könsöverskridanden. I verk som J.-K. Huysmans À rebours (1884, Mot strömmen) Charles Baudelaires Les Fleurs du mal (1857, Ondskans blommor) och Oscar Wildes The Picture of Dorian Gray (1891, Dorian Grays porträtt) tematiseras förbjudna samkönade begär och samma sak skedde i verk av nordiska författare som Herman Bang och Ola Hansson. ${ }^{11}$

Men dekadens som litterär stil och som uttryck hos huvudpersonen är inte särskilt väl förankrad i berättelsen i övrigt och avviker från hur Thyra annars brukar tänka. Också martyrmotivet dyker upp i ovanstående passage. I Bibelns berättelse vill Pilatus, på hustruns inrådan, skona Jesus och han ber därför folket att välja om han ska frige den fridsamme Jesus eller den grovt kriminelle Barabbas. Tvärtemot hur Pilatus hade tänkt sig det hela vill folket fria Barabbas samtidigt som det kräver att Jesus skulle korsfästas. Oklart är vad Thyra menar med orden: "Släpp Barabam lös, du människobarn!" Tänker hon sig att hon ska bejaka relationen med Viveka? Att det homoerotiska begäret är det vilddjur som ska släppas lös? Eller ska hon ägna sig åt heterosexuella utsvävningar medan de samkönade ska offras? Här, som så ofta, är texten ambivalent. 
Dagen därpå dyker Lisa upp igen och med sig har hon pinfärskt skvaller om Viveka, som hon har fått från sin kamrat Inez Törneblad - Inez efternamn anknyter till martyrmotivet. Det visar sig att det var denna Inez som bekikade Viveka och Thyra på operan kvällen före. Inez Törneblad säger att Viveka "skaffat sig ett nytt syndaoffer". Utan att veta om att det är Thyra som är "offret" berättar Lisa att Viveka är "en sådan där en ... en sådan där, som har till specialitet att dra till sig unga flickor...” (85). Thyra svimmar när hon hör detta. Sedan är det dags för Viveka att göra entré i Thyras ateljé. Thyra är rasande på henne och beskyller Viveka för att ha förstört hennes liv. Men för andra gången i berättelsen blir Viveka nu arg och säger ifrån:

- Du hatar mig icke, sade hon lågt och fast, med isande kall röst. Spara dina stora ord, med dem imponerar du inte på mig... Jag har förstört ditt liv, säger du, gjort dig till brottsling. Du har följt ditt blods röst, om du nu kallar det ett brott ... (88)

Återigen gör hon anspråk på att känna Thyra bättre än hon känner sig själv. Och sedan börjar Viveka berätta sitt eget livs historia. Det visar sig att Inez Törneblads anklagelse inte har någon som helst grund. Någon ungdomens förförare är hon inte. Hon har bara haft en enda kvinna innan hon träffade Thyra, nämligen den som hon nu lever med.

Sedan berättar hon om varför hon en gång började leva lesbiskt - och här kommer en historia som är bättre förankrad i samtida sexologiska teorier än i den berättelse den ingår i. Viveka har en gång varit lyckligt gift, men mannen dog redan efter en kort tids äktenskap utan att paret hade hunnit få några barn. Utom sig av sorg reste hon efter mannens död planlöst runt i världen.

Det var då, därute, jag mötte henne, som nu är min vän... Hon var en stackars själ, som hungrat och törstat efter lyckan sen sin tidiga barndom, och när den aldrig kom, tog hon till sist den, hon kunde få med minsta risk... Den gången ryste jag som du gör nu. Men nu är det annorlunda. Nu förstår jag inte längre, vad ont det är i sådant. Nu ser jag vad det är för oss kvinnor: ett surrogat, 
inte urartning. Och därför om två människor kan känna så och ge varandra en smula lycka på det sättet - nåväl, det må väl vara deras sak... (91-92)

Denna livshistoria påminner som vi ser starkt om den som Elisabeth Dauthendey berättar om i den tidigare diskuterade Ny kärlek. Två ensamma kvinnor, som rotlösa flackar runt i världen, söker, i brist på bättre, trygghet och kärlek hos varandra. Den samkönade kärleken sägs alltså vara ett surrogat för den olikkönade. Denna förklaring liknar också den den som finns i Frida Stéenhoffs dramer, men med den skillnaden att det hos Gille otvetydigt handlar om erotik och inte bara svärmisk vänskap.

I sin berättelse om hur hon själv kom att leva med kvinnor tillbakavisar Viveka de vanligaste föreställningarna om samkönad kärlek: Den är inte en "synd", som kyrkan sa. Den är inte något "orätt", alltså något brottsligt, som staten sa. Det är inte fråga om "urartning", som socialdarwinisterna menade och samkönad kärlek är inte heller "föraktlig", som den tidens allmänna mening nog hävdade att den var. Men eftersom männen aldrig framställs som erotiska frestelser för kvinnorna i texten blir argumentet krystat. Tanken att samkönad kärlek bara handlar om att "ge varandra en smula lycka" i en hård värld är helt enkelt inte förankrad i texten. Ändå imponerar den på Thyra, som nu vill omvända Viveka till att "bli som förr", vilket, får man förmoda, innebär att hon ska sluta att älska kvinnor. Viveka svarar dock att "sådant icke bara är en viljeakt..." (93).

Thyra kastas hela tiden fram och tillbaka mellan känslomässiga ytterligheter. På natten efter ovanstående scen skriver hon ett brev till Viveka där hon föreslår att de ska hjälpas åt att bekämpa sina erotiska känslor för varandra. De ska avstå från den kroppsliga kärleken och i stället närma sig den andliga. Själv är hon i skrivande stund säker på att detta är det enda rätta att göra, så säker att hon för en tid lyckas övertala Viveka om saken. Frågan är om vi som läsare blir lika övertygade. Thyra skriver sitt brev en kväll när hennes granne, en halvgammal pianolärarinna, spelar ett stycke kallat "Glückes genug". Grannkvinnan lever ensam och i små omständigheter och Thyra tänker att hon nog spelar för att "trösta sig över en eländig, glädje- 
fattig tillvaro". (95) Grannen blir sinnebilden för den "förkrympta, vissnade, ofärdiga varelse" som tidigare föraktfullt avfärdades i den långa inre monologen och en föraning om den ensamma kvinna Thyra själv riskerar att bli om hon fortsätter att bekämpa sina egna och Vivekas känslor. Thyra må vara övertygad om det rimliga i sin föresats, men berättelsen är det inte. Viveka kallar henne för en "underlig blandning av sunt förnuft och känslosamhet, självkännedom och självbedrägeri ..." (106) och det kan tänkas att läsaren håller med.

Viveka fortsätter att i all kyskhet besöka henne i ateljén om kvällarna, trots att Thyra fortsätter med sin avhållsamhetskampanj. Men så händer det som Thyra försöker intala sig själv att hon inte vill ska hända:

En afton, då mörkret låg sammetstungt över ateljén och en ensam glöd lyste fram under falaskan med ett slocknande ögas outgrundliga blick, drev blodets vågor henne dit, där ingen återvändo mer finns. Allt inom henne önskade och ville blott ett. Gränserna mellan gott och ont flöto samman och plånades ut. Så lyfte hon lustans bägare och drack på nytt dess röda, glödande vin ... (108)

Därefter fortsätter de att umgås intimt med varandra, trots att Thyra hela tiden kastas fram och tillbaka mellan hängivelse och ruelse. Tills att Viveka en dag säger att de inte kan träffas mer, eftersom hennes väninna nu kommer tillbaka från sin resa. Thyra blir förstås förtvivlad och anklagar Viveka för att ha fört henne i fördärvet, men då blir Viveka återigen irriterad:

- Du talar om, att jag lockat dig in i fördärv och elände. Det är fraser och tomma ord. När två människor, så beskaffade som du och jag, mötas, så måste resultatet med naturnödvändighet bli, som det nu blivit... Det är nonsens att tala om, att den ena lockar och den andra blir lockad ... Lockar kanske havet bäckar och åar? Söker de sig inte dit alla ändå? ... (111)

Här avvisar Viveka ännu en klichéföreställning om homosexualitet, 
nämligen den att den är orsakad av att den ena parten, den perverterade, förför en oskuldsfull person till perversion.

Thyra kastar sig in i arbete, får goda recensioner när hon visar sina målningar på en offentlig utställning och går ganska glad till vernissagen. Men det bär sig inte bättre än att Viveka och hennes väninna är där, och när Thyra hälsar på henne uppträder Viveka så kyligt att Thyra återigen kastas ner i förtvivlan. Viveka försöker släta över det hela genom att skicka röda rosor och förklara sitt uppförande i ett brev: "Du vet ju, att folk pratar om mig. Och jag vill inte genom oförsiktighet skada dig, som är så dyrbar för mitt hjärta." (124) Men den här gången når orden inte fram.

Thyra finner inte längre något nöje $i$ arbetet utan går allt djupare in i en kris. Ateljén som tidigare utgjort hennes hem och hennes värld känns tom och ogästvänlig. ”Den gamla åbäkiga kakelugnen lutade sig mot väggen stelt avvisande som en människa, som känner sig övergiven och omaka i en främmande miljö." (125) Ibland tycker hon att kakelugnen stirrar föraktfullt och förebrående på henne som "en domare". Annat hade det varit några månader tidigare då hon tillsammans med Viveka satt framför kakelugnen om kvällarna och såg hur rökvirvlarna från Vivekas cigarett sögs in i kakelugnen:

Det var som ett helt drama att se dem svinga upp i luften i stolt frihet, som yvdes de över egen kraft, se dem plötsligt stanna, villrådigt börja vackla hit och dit, som om de togo spjärn och sökte värja sig mot en frestares anlopp, tills de med ens gripna av vild, oemotståndlig yra, uppgåvo all strid och störtade fram mot fördärvet och läto sig slukas upp av kakelugnens glödande gap... (104)

Den gången representerade kakelugnen passionens hetta - nu blir den sinnebilden för undergång och främlingskap i världen. Thyra känner sig olycklig och ensam, men så kommer hon att tänka på Lisa, "den enda människa, som stod henne riktigt nära, som hon kunde lita på, förtro sig till - om det gällde." (143) Men det ska visa sig att Lisa inte alls är så pålitlig som hon trott. När det verkligen gäller så sviker hon. 
Lisa berättar för Thyra att hon i sällskap med Inez Törneblad har stött ihop med Viveka, som satt i en av "Freys elegantaste vagnar och med en förtjusande söt ung flicka bredvid sig" (145). De drar slutsatsen att de båda kvinnorna i vagnen är ett par och detta berättar hon nu för Thyra som blir än mer förtvivlad. Till och med så förtvivlad att hon berättar för Lisa om sin relation med Viveka, men Lisa känner bara "fasa och vämjelse" och har ingen tröst och ingen sympati att ge. Thyra är precis så ensam som hon känner sig.

I sin förtvivlan söker Thyra upp Viveka en sista gång och konfronterar henne med det som Lisa har berättat. Hon gör det, som hon säger, för att be Viveka att "ha miskund och förbarmande och inte störta flera i samma helvete" som hon själv befinner sig i. (166) Det visar sig då att den kvinna Viveka varit med på Djurgården inte alls var någon ny älskarinna utan en systerdotter. Återigen har förtalet alltså varit grundlöst. Återigen säger Viveka att hon känner Thyra bättre än hon känner sig själv. Och återigen ger Thyra efter för blodets röst.

\section{Mot djupet. Mot himmelrik}

"Auf Wiedersehn - auf Wiedersehn i morgon", ropar Viveka efter Thyra när hon går nedför trapporna, men detta kärleksmöte är deras allra sista. De stridiga känslorna har till slut slitit sönder Thyra. Hon går till Norrbro, ser ner i vattnet och känner samma dragningskraft från strömmens virvlar som hon tidigare har känt inför erotikens. Hon klättrar upp på broräcket.

Ett ögonblick blev hon stående däruppe. Hon bredde ut armarna, som ville hon famna världen ännu en sista gång. Ett svagt, hisnande rop banade sig väg över [h]ennes läppar. I en stor båge störtade hon ned i det ilande, dansande vattnet. (177)

Thyra breder ut armarna "som ville hon famna världen" står det i citatet, men man kan också se det som att hon inför dödssprånget formar sin kropp till ett korstecken, att scenen alltså anknyter till det martyrmotiv som har funnits med redan från romanens första 
sida där det står att Thyra "med lismande judaskyssar" förråddes av sitt öde.

Man kunde tro att berättelsen skulle vara slut här, men det är den inte. Gille har lagt till ett avslutande kapitel där Thyra, genom en slumsysters omsorger, räddas tillbaka först till kroppens liv och sedan till ett kristligt liv. Hon blir fri från sina "synder" och börjar arbeta i Frälsningsarmén. Slumsystern har med ihärdigt bedjande fått henne att lämna sitt världsliga liv för att i stället gå in i det andliga, ungefär så som Thyra själv en gång tänkte sig att hon skulle kunna hjälpa Viveka. Hon har kommit över kärlekens kval, men hon har gjort det till priset av sig själv. Brottet, det samkönade begäret, blir sonat och ordningen blir återställd, men brottslingen, hon som romanen handlar om, har blivit en annan, någon som romanens berättare inte längre är särskilt intresserad av.

Romanen slutar, precis som den börjar, med att Thyra och den känslovärld som är berättelsens centrum, betraktas utifrån, från ett heteronormativt perspektiv. På så sätt skapas distans till det förbjudna. Vad som hände med Viveka får vi inte veta. Hon besöker Thyra när hon ligger sjuk, men avvisas. Hon skriver brev till henne, men Thyra öppnar dem inte. Om hon av människorna i Thyras omgivning ständigt beskylls för att vara en kallhamrad serieförförerska, fungerar dessa och många andra detaljer som korrektiv och bidrar till att skapa en sammansatt karaktär. Lisa, Inez, Gerle och alla de andra har helt enkelt haft fel i sin bedömning av henne. Hon må vara vacker, erotiskt företagsam och svag för lyx, men något monster är hon inte. Hon kan gråta. Hon kan längta. Och hon visar sig vara långt mer trofast i kärlek än hon först syntes vara.

Viveka har vissa demoniska drag, eller vampyriska om man så vill, men om man jämför porträttet av henne med andra vampyrer i den samtida konsten och litteraturen, framstår hon som sympatisk. I novellsamlingen Vampyrer (1918) beskrev den svenske populärförfattaren Algot Sandberg relationer mellan kvinnor som just vampyrism. I hans berättelser biter sig starka och hänsynslösa kvinnor fast på veka oskuldsfulla kvinnor och suger sedan systematiskt i sig offrets livskraft så att det slutligen inte återstår mer än ett tomt och livlöst skal. ${ }^{12}$ Den vampyriska kvinnan hatar män och barn, älskar 
lyx och droger, och hennes erotik handlar inte om kärlek. "Kärlek" mellan kvinnor är i Sandbergs novellsamling i själva verket ett annat ord för "exploatering" och kan bara sluta med den ena partens - eller bådas - undergång.

Visst finns det inslag i romanen som associerar Viveka med det vampyriska och Thyra med hennes offer. Men det finns också återkommande detaljer, i såväl bildspråket som i det skildrade skeendet, som gör dem båda till kärlekens martyrer. Den bild romanen ger av den samkönade kärleken är alltså djupt ambivalent.

Det är otvetydigt så att relationen mellan kvinnorna är av sexuell art. Erotiken framställs som en naturkraft som man inte kan stå emot utan att något väsentligt går förlorat. Romanen kritiserar den dubbelmoral som gör livet så svårt, särskilt för kvinnorna, och udden riktas både mot patriarkalismen och heteronormativiteten. Men samtidigt reproduceras dessa maktordningar genom hur händelserna skildras och genom att de finns inskrivna i huvudpersonens känsloliv. Resultatet blir ambivalens. Det motsägelsefulla formuleras $i$ en lång replik av Viveka.

- Låt bli det där skenheliga pratet! Inte vill du väl, att jag efter detta skall ta sådant pjoller för gott. Sannerligen jag förstår dig ... Först jag såg dig trodde jag, att du hörde till dessa enkla, storstilade människor, som jag alltid satt så högt... men förlåt mig min uppriktighet, du har ingen karaktär... eller åtminstone en dålig sådan: Ena minuten talas det hycklande om ånger och samvetskval, andra minuten hör du inte på mig, då jag med tanke på "dina lidanden" vill hejda och varna dig ... Då säger du dig vara på andra sidan kälkborgarmoralens gott och ont. Nästa stund är jämmern i full gång igen och talet om "Gud" och "Gudsmening" och allt det där ... Vad skall jag väl tänka om sådant, säg själv! (112) 